\title{
Inverter Tiga Fasa untuk Pembangkit Listrik Tenaga Surya
}

\author{
Asnil ${ }^{\# 1}$, Krismadinata ${ }^{\# 2}$, Irma Husnaini ${ }^{\# 3}$ \\ \# Teknik Elektro Universitas Negeri Padang \\ Jl. Prof. Dr. Hamka. Air Tawar Padang, Sumatera Barat-Indonesia \\ asnil81eft.unp.ac.id, ${ }^{2}$ krismalft.unp.ac.id, 3 irma hnnilyahoo.com
}

\begin{abstract}
Abstrak- Makalah ini membahas mengenai metode konduksi sebuah inverter tiga fasa dengan sumber tegangan (VSI) dalam upaya mengurangi Total Harmonic Histortion (THD) tegangan keluaran untuk penggunaan pada pembangkit listrik tenaga surya. Untuk mendapatkan hasil yang lebih baik, digunakan metode konduksi $\mathbf{1 5 0}^{\circ}$, dimana setiap saklar pada inverter tiga fasa terkonduksi selama periode waktu $150^{\circ}$. Jika dibandingkan dengan metode konduksi $120^{\circ}$ dan metode konduksi $180^{\circ}$ sebagai mana yang banyak digunakan pada inverter tiga fasa, maka metode konduksi $150^{\circ}$ menunjukan pengurangan THD tegangan keluaran yang lebih baik. Dari simulasi yang dilakukan, metode konduksi $150^{\circ}$ mengasilkan tegangan fasa keluaran 7 level. Jika dibandingkan dengan metode konduksi $180^{\circ}$ dan $120^{\circ}$ yang tegangan fasa keluarannya hanya 4 level dan 3 level. Nilai THD inverter tiga fasa menggunakan sudut konduksi $120^{\circ}$ didapatkan sebesar $31,09 \%$, menggunakan sudut konduksi $180^{\circ}$ didapatkan sebesar 31,10\%, namun menggunakan sudut konduksi $150^{\circ}$ didapatkan sebesar $16,85 \%$. Metode konduksi $150^{\circ}$ dapat menurunkan nilai THD yang signifikan yakni sebesar 53,31\%. Dengan kata lain semakin kecil THD maka bentuk keluaran akan semakin mendekati sinusoidal sehingga kinerja inverter juga akan semakin baik.
\end{abstract}

Kata Kunci - Inverter, metode konduksi, Total Harmonic Distortion (THD)

\section{PENDAHULUAN}

Inverter dipakai pada banyak aplikasi, seperti Variable Frequency Driver (VFD), filter aktif, UPS, FACTS, Power Generation System, Grids, Renewable Sources (Photovoltaic System), Fuel cells, wind farms danpengaturan kecepatan motor [1], [2], [3]. Idealnya sebuah inverter memiliki bentuk tegangan keluaran sinusoidal namun dalam prakteknya tidak sinusoidal dan juga mengandung harmonik. Gelombang keluaran persegi ataupun yang dimodifikasi (quasi square wave) memungkinkan untuk dipakai pada aplikasi daya rendah dan menengah, namun untuk aplikasi daya tinggi dibutuhkan bentuk sinusoidal dengan distorsi yang seminimal mungkin. Mengurangi nilai riak tegangan keluaran dapat digunakan topologi multi level inverter namun kelemahannya membutuhkan lebih banyak komponen semikonduktor dan sistem kontrol yang lebih komplek [4], [5],[6]. Cara lain yang dapat digunakan untuk mengurangi riak tegangan keluaran dari inverter adalah dengan menggunakan teknik pensaklaran [7].

\section{TINJAUAN PUSTAKA}

Inverter dipakai pada banyak aplikasi yang fungsi utamanya adalah untuk mengubah tegangan searah menjadi tegangan bolak balik. Untuk pemilihan inverter tersedia berbagai topologi sesuai dengan kebutuhan seperti Voltage Source Inverter (VSI) dan Current Source Inverter (CSI) baik satu fasa, tiga fasa ataupun multilevel. VSI memberikan kinerja yang lebih baik dan juga lebih efisien dari pada CSI [8].

Rangkaian dasar inverter tiga fasa dapat dilihat pada gambar 1, terdiri dari 6 buah komponen pensaklaran dengan sudut konduksi yang berbeda. Dalam sistem pembangkit listrik tenaga surya, inverter merupakan komponen utama untuk mengkonversikan tegangan searah menjadi tegangan bolak-balik sesuai dengan kebutuhan beban.

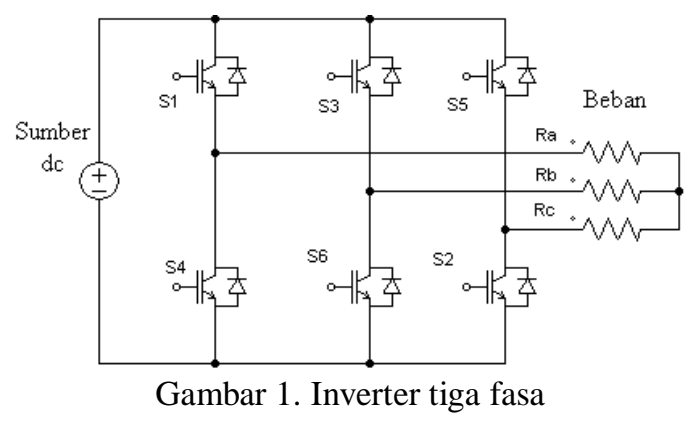

Teknik pensaklaran yang umum digunakan adalah $120^{\circ}$ dan $180^{\circ}$. Namun pada tilisan ini digunakan teknik pensaklaran dengan sudut konduksi $150^{\circ}$ yang kemudian dibandingkan dengan sudut konduksi $120^{\circ}$ dan $180^{\circ}$. Metode ini diterapkan pada rangkaian seperti gambar 1 dengan beban seimbang yang dihubungkan secara bintang.

\section{A. Teknik pensaklaran $120^{\circ}$}

Inverter tiga fasa dengan metode konduksi $120^{\circ}$ memungkinkan setiap komponen pensaklaran akan terkonduksi selama periode waktu $120^{\circ}$. Pada metode ini, dua saklar akan konduksi secara bersamaan selama selang waktu $60^{\circ}$. Operasi pensaklaran untuk metode konduksi $120^{\circ}$ dapat dilihat pada tabel 1 . 
TABEL 1

KONFIGURASI PENSAKLARAN INVERTER TIGA FASA MODE KONDUKSI $120^{\circ}$

\begin{tabular}{|c|c|c|c|c|c|c|c|c|}
\hline Interval & Durasi & \multicolumn{2}{|l|}{ Saklar } & \multicolumn{1}{l|}{} \\
\hline 1 & $120^{0}$ & S1 & S2 & & & & & \\
\hline 2 & $120^{0}$ & & S2 & S3 & & & & \\
\hline 3 & $120^{0}$ & & & S3 & S4 & & & \\
\hline 4 & $120^{0}$ & & & & S4 & S5 & & \\
\hline 5 & $120^{0}$ & & & & & S5 & S6 & \\
\hline 6 & $120^{0}$ & & & & & & S6 & S1 \\
\hline
\end{tabular}

Setiap $60^{\circ}$, salah satu saklar akan terputus atau off dan saklar yang lain akan terhubung atau on. Dengan kata lain, terdapat delay waktu selama $\pi / 6$ antar saklar off dan on sehingga tidak ada kemungkinan terjadi hubung singkat. Untuk menghitung nilai rms tegangan keluaranya dapat digunakan persamaan (1).

$$
\begin{aligned}
& V_{A N}=\sum_{n=1,3,5, . .}^{\infty} \frac{2 V_{D C}}{n \pi} \sin \left(\frac{n \pi}{3}\right) \sin \mathrm{n} \quad(\omega t+ \\
& \left.\frac{\pi}{6}\right) \ldots(1)
\end{aligned}
$$

\section{B. Teknik pensaklaran $180^{\circ}$}

Pada metode ini, setiap saklar akan konduksi selama $180^{\circ}$ dan dan tiga saklar akan konduksi secara bersamaan. Dua buah saklar dari group positif dan satu saklar dari group negatif atau sebaliknya. Sama halnya dengan metode $120^{\circ}$, metode ini juga pada setiap $60^{\circ}$ terjadi pergantian pensaklaran off dan on. Pada metode ini, kemungkinan adanya hubung singkat antar saklar bisa terjadi karena tidak ada terdapat waktu tunda untuk on dan off dari saklar group positif dan negatif atau sebaliknya. Untuk menghitung nilai tegangan keluaran dapat digunakan persamaan (2).

$$
V_{A N}=\sum_{n=1,3,5, . .}^{\infty} \frac{4 V_{D C}}{\sqrt{3} n \pi} \sin \left(\frac{n \pi}{3}\right) \sin \quad(n \omega t)
$$

Operasi pensaklaran untuk metode konduksi $180^{\circ}$ dapat dilihat pada tabel 2 .

TABEL II

KONFIGURASI PENSAKLARAN INVERTER TIGA FASA MODE KONDUKSI $180^{\circ}$

\begin{tabular}{|c|c|c|c|c|c|c|c|c|c|}
\hline Interval & Durasi & \multicolumn{7}{|c|}{ Saklar } \\
\hline 1 & $120^{0}$ & S1 & S2 & S3 & & & & & \\
\hline 2 & $120^{0}$ & & S2 & S3 & S4 & & & & \\
\hline 3 & $120^{0}$ & & & S3 & S4 & S5 & & & \\
\hline 4 & $120^{0}$ & & & & S4 & S5 & S6 & & \\
\hline 5 & $120^{0}$ & & & & & S5 & S6 & S1 & \\
\hline 6 & $120^{0}$ & & & & & & S6 & S1 & S2 \\
\hline
\end{tabular}

\section{Teknik pensaklaran $150^{\circ}$}

Teknik pensaklaran menggunakan metode konduksi $150^{\circ}$, setiap saklar akan terkonduksi selama priode waktu $150^{\circ}$. Berbeda dengan metode pensaklaran $120^{\circ}$ dan $180^{\circ}$, metode pensaklaran $150^{\circ}$ terdiri dari dua belas tahap pensaklaran dan durasi konduksi dari setiap saklar adalah selama $30^{0}$ seperti yang terdapat pada tabel 3. Tahap pertama terdapat tiga saklar yang terkonduksi secara bersamaan berikutnya dua saklar yang terkonduksi secara bersamaan selama $30^{\circ}$ kedua. Begitu seterusnya berulang untuk tahapan $30^{\circ}$ berikutnya sampai dua belas tahap hingga terbentuk satu gelombang penuh. Secara rinci, operasi pensaklaran untuk metode konduksi $150^{\circ}$ dapat dilihat pada tabel 3 .

Untuk menghitung nilai tegangan keluaran dapat digunakan persamaan (3).

$$
\begin{aligned}
V_{A N}= & \sum_{n=1,3,5, \ldots}^{\infty}\left[4+\cos \left(\frac{n \pi}{6}\right)+\cos \left(\frac{n \pi}{3}\right)-\right. \\
& \cos \left(\frac{2 n \pi}{3}\right)-2 \cos \left(\frac{5 n \pi}{6}\right)-\cos \left(\frac{4 n \pi}{3}\right)+ \\
& \left.\cos \left(\frac{5 n \pi}{3}\right)+2 \cos \left(\frac{11 n \pi}{6}\right)\right] \sin \left(\omega t+\frac{\pi}{6}\right)
\end{aligned}
$$

TABEL III

KONFIGURASI PENSAKLARAN INVERTER TIGA FASA MODE KONDUKSI $150^{\circ}$

\begin{tabular}{|c|c|c|c|c|c|c|c|c|c|}
\hline Interval & Durasi & \multicolumn{7}{|c|}{ Saklar } \\
\hline 1 & $30^{0}$ & S1 & S2 & S3 & & & & & \\
\hline 2 & $30^{0}$ & & S2 & S3 & & & & & \\
\hline 3 & $30^{0}$ & & S2 & S3 & S4 & & & & \\
\hline 4 & $30^{0}$ & & & S3 & S4 & & & & \\
\hline 5 & $30^{0}$ & & & S3 & S4 & S5 & & & \\
\hline 6 & $30^{0}$ & & & & S4 & S5 & & & \\
\hline 7 & $30^{0}$ & & & & S4 & S5 & S6 & & \\
\hline 8 & $30^{0}$ & & & & & S5 & S6 & & \\
\hline 9 & $30^{0}$ & & & & & S5 & S6 & S1 & \\
\hline 10 & $30^{0}$ & & & & & & S6 & S1 & \\
\hline 11 & $30^{0}$ & & & & & & S6 & S1 & S2 \\
\hline 12 & $30^{0}$ & & & & & & & S1 & S2 \\
\hline
\end{tabular}

\section{HASIL DAN PEMBAHASAN}

Dari simulasi yang dilakukan didapatkan unjuk kerja rangkaian seperti pada gambar 1. Parameter yang digunakan adalah $\mathrm{Vdc}=240$ volt, dihubungkan dengan beban resistor yang dihubung bintang, masingmasing $100 \mathrm{Ohm}$. Gambar 2, gambar 3 dan gambar 4 adalah bentuk gelombang tegangan keluaran antar fasa, masing-masing menggunakan metode konduksi $120^{\circ}$, konduksi $180^{\circ}$ dan konduksi $150^{\circ}$. 


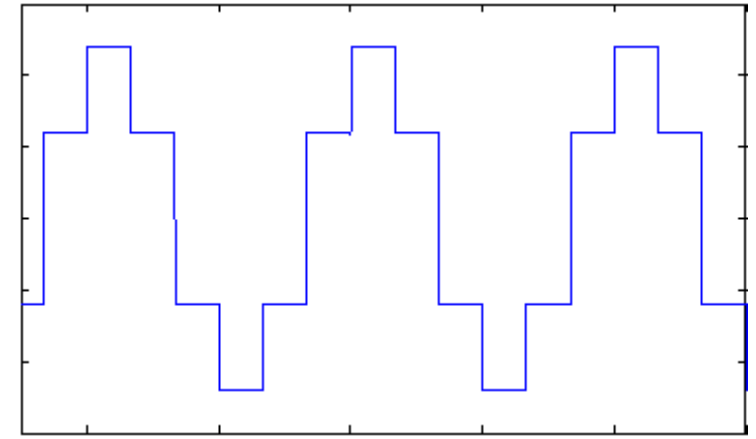

Gambar 2. Tegangan antar fasa dengn metode konduksi $120^{\circ}$

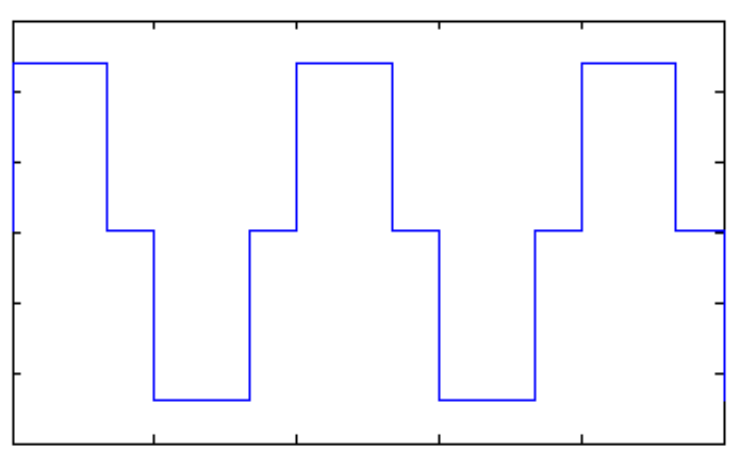

Gambar 3. Tegangan antar fasa denga metode konduksi $180^{\circ}$

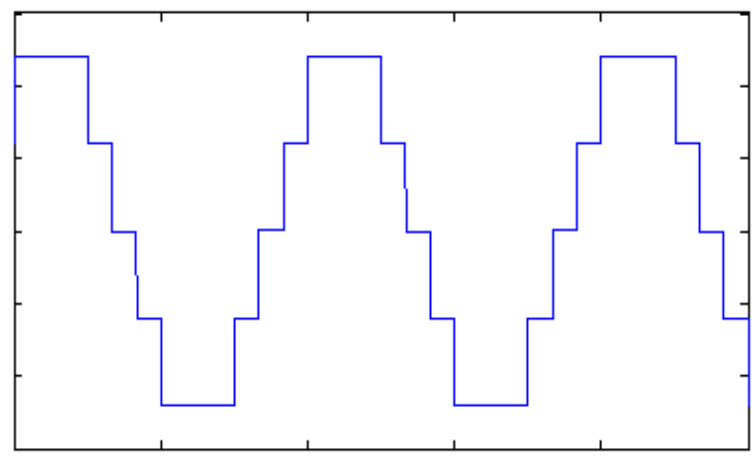

Gambar 4. Tegangan antar fasa dengan metode konduksi $150^{\circ}$

Perbedaan masing-masing tegangan terletak pada level tegangan keluaran. Metode konduksi $120^{\circ}$ mengasilkan tegangan antar fasa keluaran 4 level, metode konduksi $180^{\circ}$ menghasilkan tegangan antar fasa keluaran 3 level dan metode konduksi $150^{\circ}$ menghasilkan tegangan keluaran antar fasa 5 level. Dengan demikian, bentuk gelombang yang mendekati bentuk sinusoidal adalah inverter dengan metode konduksi $150^{\circ}$. Dengan artian semakin banyak level tegangan maka gelombang tegangan tersebut akan semakin mendekati bentuk sinusoidal.

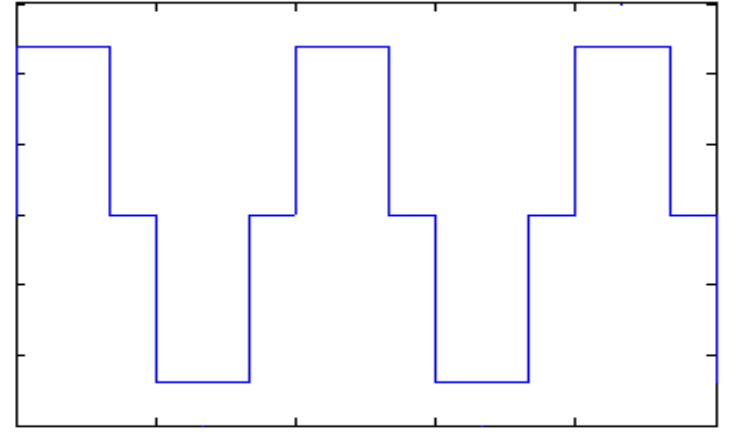

Gambar 5. Tegangan fasa netral dengan metode konduksi $120^{\circ}$

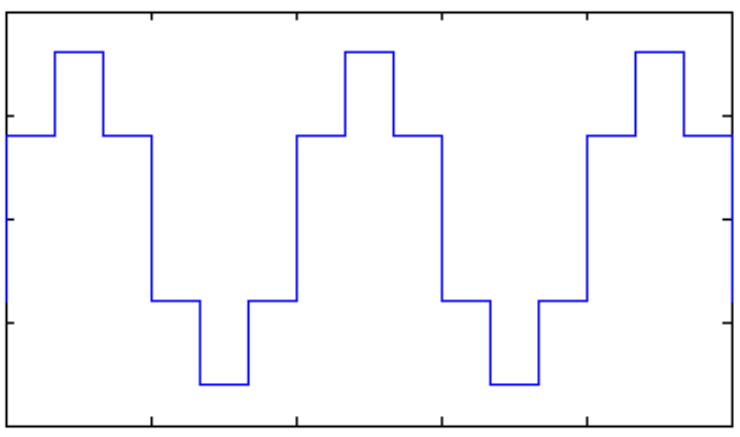

Gambar 6. Tegangan fasa netral dengan metode konduksi $180^{\circ}$

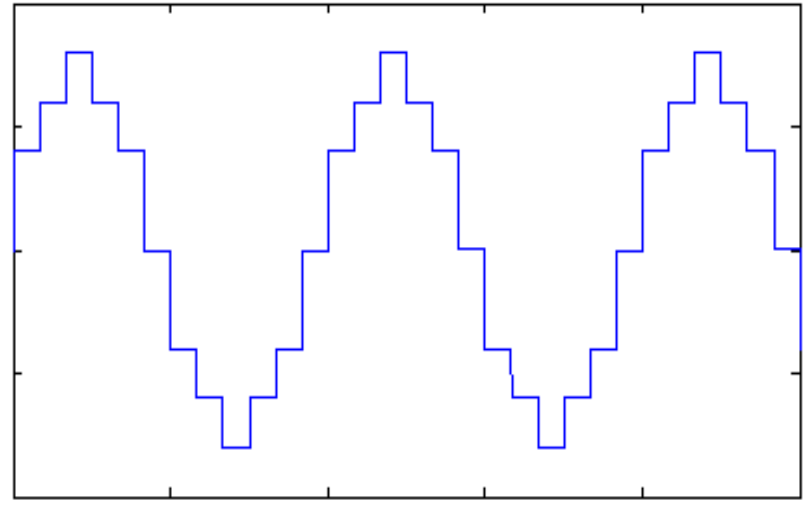

Gambar 7. Tegangan fasa netral dengan metode konduksi $150^{\circ}$

Pada gambar 5, gambar 6 dan gambar 7 terlihat perbedaan bentuk tegangan fasa netral masing-masing metode konduksi yang digunakan. Metode konduksi $120^{\circ}$ menghasilkan tegangan keluaran inverter fasa netral 3 level, metode konduksi $180^{\circ}$ menghasilkan tegangan keluaran inverter fasa netral 4 level dan metode konduksi $150^{\circ}$ menghasilkan tegangan keluaran inverter fasa netral 7 level. Dengan demikian metode konduksi $150^{\circ}$ juga menghasilkan bentuk tegangan keluaran fasa netral lebih baik dari pada metode $120^{\circ}$ dan metode $180^{\circ}$. Hasil lain yang didapatkan adalah hasil simulasi menggunakan metode konduksi $120^{\circ}$ dan $180^{\circ}$ antar fasa adalah kebalikan dari hasil tegangan fasa netralnya.

Pada gambar 8, gambar 9 dan gambar 10 dapat dilihat analisa presentasi harmonik dari tegangan fasa netral untuk setiap metode konduksi yang digunakan. 


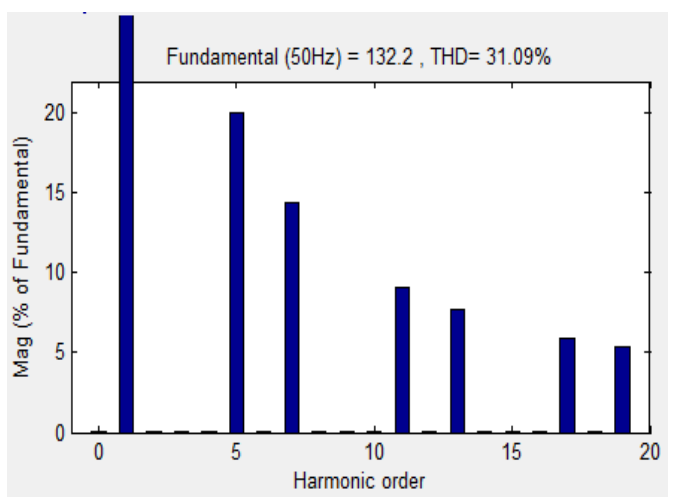

Gambar 8. Persentase harmonik dengan metode konduksi $120^{\circ}$

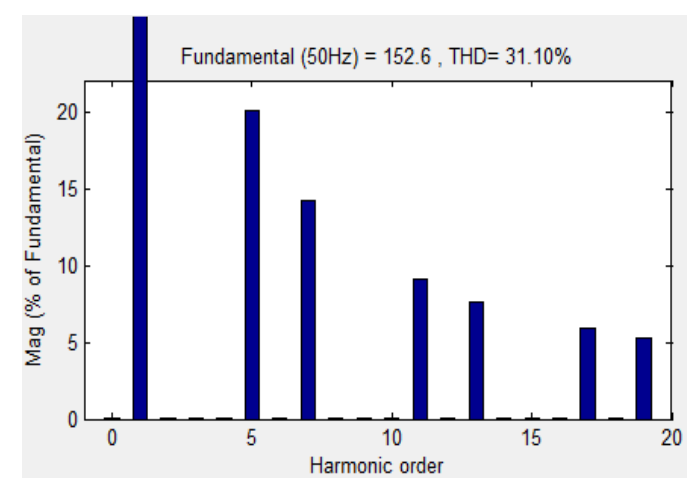

Gambar 9. Persentase harmonik dengan metode konduksi $180^{\circ}$

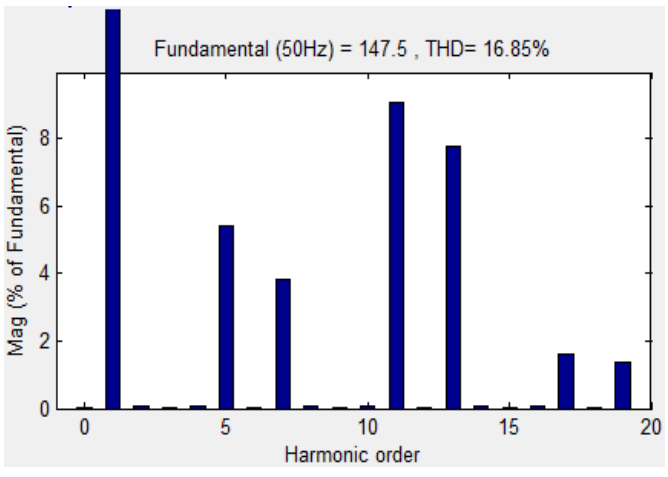

Gambar 10. Persentase harmonik dengan metode konduksi $150^{\circ}$

TABEL 4

PERBANDINGAN HASIL MASING-MASING KONFIGURASI PENSAKLARAN

\begin{tabular}{|l|c|c|c|}
\hline \multicolumn{1}{|c|}{ Parameter } & $\mathbf{1 2 0}^{\mathbf{0}}$ & $\mathbf{1 5 0}^{\mathbf{0}}$ & $\mathbf{1 8 0}^{\mathbf{0}}$ \\
\hline Tegangan antar fasa & 4 level & 5 level & 3 level \\
\hline Tegangan fasa fasa & 3 level & 7 level & 4 level \\
\hline Persentase (\%) THD & 31,09 & 31,10 & 16,85 \\
\hline
\end{tabular}

Masing-masing metode konduksi yang digunakan $120^{\circ}, 180^{\circ}$ dan $150^{\circ}$ menghasilkan nilai Total Harmonic Distortion (THD) sebesar 31,09 \%, 31,10\% dan $16,85 \%$. Dengan demikian menggunakan metode konduksi $150^{\circ}$ dapat mengurangi nilai THD sampai $45,82 \%$

\section{KESIMPULAN}

Dari analisis yang dilakukan, metode konduksi $150^{\circ}$ dapat mengurangi nilai THD tegangan fasa netral inverter mencapai 45,82\%. Menghasilkan bentuk gelombang tegangan keluaran menjadi 7 level sehingga lebih mendekati bentuk sinusoidal. Dengan demikian metode konduksi $150^{\circ}$ menghasilkan nilai THD yang lebih kecil dan unjuk kerja sistem lebih baik dari pada metode konduksi $120^{\circ}$ dan metode konduksi $180^{0}$

\section{DAFTAR PUSTAKA}

[1] D. Suganya Devi, et al, Performance Improvement of Induction Motor Using Multilevel Inverter, International Journal of Emerging Technology and Advanced Engineering, Certified Journal, September 2014

[2] DarshanPrajapati, et al, A Comparative Study of Three Phase 2-Level VSI with 3-Level and 5-Level Diode Clamped Multilevel Inverter, International Journal of Emerging Technology and Advanced Engineering, Volume 4, Issue 4, April 2014.

[3] Atif Iqbal and Shaikh Moinuddin, Assessment Of Torque Pulsation In Inverter Fed Three-Phase Induction Motor Drive For $180^{\circ}$ And $150^{\circ}$ Conduction Modes, International Conference on Information and Communication Technology in Electrical Sciences (ICTES 2007).

[4] N. Srinivasa reddy, et al, Elimination of Natural Harmonics in Square Wave Inverter, IJAICT, Vol 2, Issue 11 Marech 2016, pp 1103-1107

[5] Krismadinata, Asnil, Irma Husnaini, dan Hendri, Microcontroller Based Multilevel Inverter for Photovoltaic System, Advanced Science Letters, Vol. 23, 3825-3863, 2017, pp 2859-3863

[6] Ebrahim Babaei, Mehdi Mahaei "Improving Output Voltage of Three Phase Six-Switch Inverters" TELKOMNIKA, Vol.9, No.3, December 2011, pp. 497-502.

[7] Mahendra G Mathukiya, 3 Phase Inverter With $180^{\circ}$ and $120^{\circ}$ Conduction Mode, IJMTER, Vol 4, Issue 3, March 2017, pp 113-118

[8] Ramesh Parmar, V.J. Rupapara, Three-Phase Voltage Source Inverter with $150^{\circ}$ Conduction Mode, National Conference on Emerging Trends in Computer \& Electrical Engineering (ETCEE) 2014, Atmiya Institute of Technology \& Science, Rajkot, pp 129-132. 